\title{
Design, Construction and Experimental Study of a Solar Still for Brackish Water Purification under Djiboutian Climate
}

\author{
Mohamed-awal A. Mohamed ${ }^{\# 1}$, Idil M. Elmi ${ }^{\# 2}$, Abdoul-Nasser D. Egueh ${ }^{* 3}$, Abdourachid I. Igueh ${ }^{\# 4}$,
} Daha H. Daher ${ }^{\S 5}$

${ }^{\#}$ Faculty of Sciences, University of Djibouti

RN2-RN5 croissing, B.P 1904, Djibouti, Republic of Djibouti

${ }^{1}$ mohamed-awal_abdillahi_mohamed@univ.edu.dj

2idil mouhoumed elmi@univ.edu.di

${ }^{*}$ Ministry of National Education and Vocational Training, B.P 2102, Djibouti, Republic of Djibouti

3abdoulnasser.dirieh.egueh@gmail.com

4abdourachid ibrahim igueh@univ.edu.di

${ }^{\S}$ Laboratoire des Energies Nouvelles et Renouvelables, Centre d'Etudes et de Recherche de Djibouti, Airport street, BP 486, Djibouti, Republic of Djibouti

${ }^{5}$ daha.enea@gmail.com

Abstract- A single sloped solar still were designed and fabricated to operate under Djibouti city weather condition during the period April-May 2019. In this study, a single slope solar still has been constructed from materials available on the local market. Series of experiments were carried out on solar still using brackish water. Ambient temperature, water temperature in basin, absorber plate temperature, glass cover temperature and vapor temperature were measured along with the hourly water production. This study has revelead that the vapor temperature is always above that the others temperatures for all the four days of experiments. Then, the effect of water amount in the basin on productivity of solar still was investigated using different amount of water $6 \mathrm{~L}, 8 \mathrm{~L}, 10 \mathrm{~L}$ and $12 \mathrm{~L}$. The experimental results show that the total accumulated distillate output for the single slope solar still is $2490 \mathrm{~mL}, 2390 \mathrm{~mL}, 2240 \mathrm{~mL}$ and $2015 \mathrm{~mL}$, respectively. However, it is observed that with increase in basin water amount distillate water production decreases. On the other hand, the effect of wind speed on the daily productivity of solar still is evaluated. Experimental investigations show that the cumulative productivity increases when the wind speed average increase. Finally, water quality analyses were conducted before and after the experiments. The average analysis results obtained showed a removal efficiency of $98.16 \%, 98.42 \%, 97.43 \%$ and $\mathbf{9 5 . 3 9 \%}$ for TDS, electrical conductivity, hardness water and chloride, respectively. It was also observed that data obtained of the product water were within the normal range prescribed by World Health Organization (WHO) standards.

Keyword- Single slope solar still, Brackish water, Purification, Djibouti, Climate.

\section{INTRODUCTION}

Water is an essential element for the continuity and development of life of all creatures as well as for vegetation and sanitation on earth. The total volume of water in the world is estimated at around 1.4 billion $\mathrm{km}^{3}$ $99 \%$ of which is salty, brackish or frozen, the rest being fresh and drinking water. Fresh water intended for human consumption is very unevenly distributed around the world. Only ten countries share $60 \%$ of fresh water reserves while nine others mainly in Africa and the Middle East are facing chronic water stress in fresh water [1]-[2].

The Republic of Djibouti is located in the northeast of the African continent, between the Aden Gulf and the Red Sea. It has a population of about 965598 with an area of $23.200 \mathrm{~km}^{2}$ [3]. Djibouti is characterized by the severity of its climatic conditions. The climate is hot and dry. Temperatures are ranging from $30^{\circ} \mathrm{C}$ to over $45^{\circ} \mathrm{C}$ resulting in a high potential evapotranspiration of more than $2000 \mathrm{~mm}$ on average. Annual rainfall is low (150 $\mathrm{mm} /$ year on average) and irregular. Djibouti is one of the countries of the lowest water resources in the world, most of which comes from aquifers. The over-exploitation of aquifers and the high pumping rate contribute to an increase in the salinity, thus leading to development of brackish water. The salinity of much of this water greatly exceeds the standards of the World Health Organization (WHO) [4]. However, tap water is drinkable, but its quality is not guaranteed (problems of infiltration in the pipes in case of rain, for example) and a rather salty flavour [5]. 
The problem of the lack of rainfall, and its consequences on the population, especially in rural areas of Djibouti, is becoming more and more recurrent in the country. The increasingly rare rains would have the direct consequence of lowering the water table as well as an increasing the salinity rate of the water, thus becoming unfit for human consumption. Rural areas are most affected by the lack of access to water because they are often located far from municipal water supply systems and conventional sources, and are not connected to the electricity grid.

In the republic of Djibouti, the access of drinkable water is a permanent challenge for the majority of the population living in rural areas. Desalination of brackish or saline water is a means of addressing the problem of providing drinking water to rural population. Concerns associated with this growing shortage have generated a wave of technological innovations in the field of water purification in the world. Conventional distillation and membrane separation processes are currently providing solutions to water needs not only for developing countries but also for industrialized countries [2]. But the major disadvantage of these processes remains the use of fossil energy that contributes to the climate change of the planet and depletion of natural resources. These processes are very costly, very energy intensive and require the use of chemicals. In recent decades, significant improvements in research and development of renewable energy sources (solar, wind turbines, etc.), clean and economical energies, have made their use a favorable response to the problems of water shortage.

On the other hand, Djibouti has a large solar energy on its territory, with the Global Horizontal Irradiance (GHI) of 4.7-7.3 kWh per square meter per day $\left(\mathrm{m}^{2} /\right.$ day) available in almost every region of the country with little variation all the year [6]. The use of abundant solar energy, is however, more efficient than using fossil fuels in remote areas with low population density and low rainfall. Solar distillation process is the best suitable solution to solve the problem of fresh water supply for small communities in arid regions with lack of drinking water with a water demand less than $50 \mathrm{~m}^{3} \cdot \mathrm{d}^{-1}$ [7]. Small-scale solar still is a device using solar energy to convert brackish or saline water to fresh drinking water. The design and fabrication of solar stills is very simple and requires less maintenance. But the main drawback is that low productivity falls in the range of 2-5 liters per day per $\mathrm{m}^{2}$ [8] and problems associated with the deposit of salt, deposit of scale and corrosion [9]. Indeed, different solar stills designs have been investigated in previous studies [10], the simplest of which is the single slope solar still widely used in solar desalination.

According to the literature, on the productivity of a solar still depends upon environmental, design, and operational parameters. However, different studies were carried out to improve the still productivity base on these parameters [11]. The solar radiation is the main parameter that affects the productivity of the solar still. Nafey et al. [12] designed and constructed four identical units of a single slope solar. They investigated the effect of the solar radiation affecting solar still performance under the same weather conditions. Their results showed that the productivity of a solar still increases with increases according to incident solar radiation. They also developed a general equation to predict the daily productivity of a single slope solar still. This equation could be used to predict the daily productivity with a reasonable confidence level (maximum error $+5 \%$ ).

The effect of water depth on the productivity of a solar still has been investigated in many publications ([13][18]). Different depths of brackish water $(0.5 \mathrm{~cm}, 2 \mathrm{~cm}, 3 \mathrm{~cm}$ and $4 \mathrm{~cm})$ with TDS of $5000 \mathrm{ppm}$ were tested under the climatic condition of Jordan. The results obtained showed that the decreased water depth has a significant effect on the increased water productivity [19]. In another study conducted by Badran and AbuKhader [20], their experimental results showed that the productivity increase $25.7 \%$ with decreasing water depth from $3.5 \mathrm{~cm}$ to $2 \mathrm{~cm}$.

Three identical conventional, basin types, single slope solar stills were designed, constructed by Alfaylakawi and Ahmed [21] and tested under the environment of Kuwait city during the month of August. They studied the effect of wind speed on the daily productivity of solar still. It has been found that increasing the wind speed from an average natural value of $1.2 \mathrm{~m} / \mathrm{s}$ to $3 \mathrm{~m} / \mathrm{s}$ and $4.5 \mathrm{~m} / \mathrm{s}$ speed up the production rate by $8 \%$ and $15.5 \%$ respectively.

Many researchers have performed distillated water quality analyses in various solar stills ([22]-[23]). Ahsan et al. [24] designed and developed a triangular solar still (TrSS), a low cost technique used in rural and coastal areas for converting saline water into potable water using solar energy. In this study, they investigated on the main parameters affecting the performance of solar still under Malaysian climate. The results obtained showed that a few essential relationships were established, e.g. between the daily production and the initial water depth, between the daily production and daily solar radiation, and between the daily production and the average ambient temperature. The $\mathrm{pH}$, Redox potential, EC, TDS and Salinity were tested for before and after water collected from solar still. The result showed that the product water are within the accepted ranges of the WHO guidelines for drinking water. Ahsan et al. [25] experimentally studied a simple solar still (SSS) for desalination a synthetic saline water samples $(1,2,3$ and $5 \%$ salt) prepared in laboratory and water samples contaminated with arsenic compound collected from Bangladesh. The water quality were tested for before and after from solar still. The values after distillation were acceptable according to the World Health Organization (WHO) and Malaysia Drinking Water Quality Standards (MAS) standards. The result showed also that the still was successful in removing arsenic compound by more than $99 \%$. Hoque et al. [26] studied saline water (synthetic 
water and real seawater) desalination with solar still in the context of Bangladesh. They evaluated saline water quality before and after distillation in the solar still and then compared with the drinking water standards. The results obtained showed a removal efficiency of with more than $99 \%$ for turbidity, chloride, TDS and electrical conductivity respectively. All of these measured parameters of the product water are within the accepted ranges of the WHO guidelines for drinking water.

The objective of the present study is to fabricate a solar still and to carry out an experimental work to investigate the effects of solar radiation, water amount in the basin and wind speed on the daily production of fresh water under Djiboutian climate. After wards, a few of water quality parameters, such as electrical conductivity (EC), $\mathrm{pH}$, total dissolved solids (TDS), hardness water and chloride, were analysed before and after distillation in the solar still in laboratory. The results of different parameters are compared with the World Health Organization (WHO) standards.

\section{MATERIALS AND METHODS}

\section{A. Working principle of solar still}

A schematic diagram and photographic view of a single slope solar still are shown in the Fig.1 and 2 respectively. The solar still design is a device allowing converting saline or brackish water into fresh water. The solar still used in this work is of a very simple design. It is a single slope solar still. It has the advantage of being easy to construct and require less maintenance. The single slope solar still is made mainly of a wooden box equipped with thermal insulation, where a still basin black painted is inserted. The wholer's covered by transparent glass inclined at a certain angle to transmit the maximum solar radiation.

The solar radiation, passing through the transparent glass, heats the brackish water or seawater contained in the absorber plate, which evaporates at high temperatures. The water vapor thus produced condenses on the internal face of the inclined transparent glass. The condensate flows and collects through a distillate channel (Fig.1).

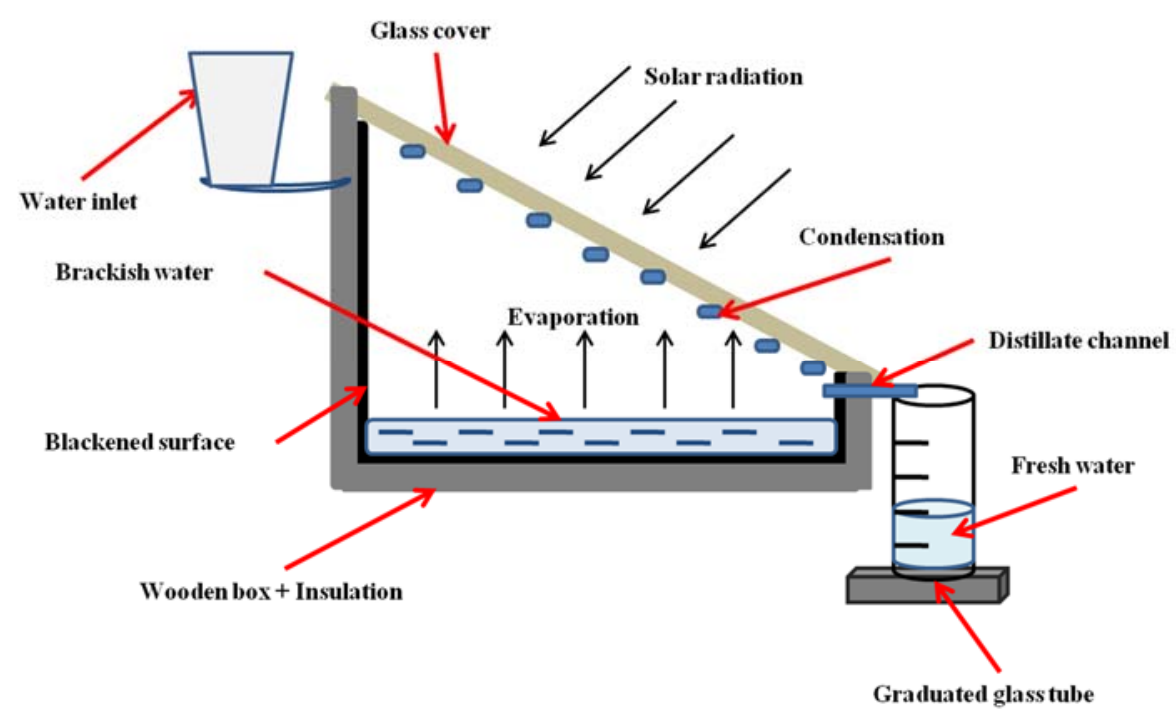

Fig. 1. Schematic diagram of single slope solar still.

\section{B. Different steps of design of components of solar still}

1) Wooden box and thermal insulation: The wooden box, exterior cover, contains the various active elements of the solar still (Fig. 1). It must therefore provide effective protection against meteorological conditions. It is made from plywood plate cut into five parts and then assembled manually using screws. The dimensions are as follows:

- Thickness: $6 \mathrm{~mm}$,

- Height: $0.7 \mathrm{~m}$ and $0.20 \mathrm{~m}$,

- Base surface area: $0.54 \mathrm{~m}^{2}$.

The inside of the wooden box is covered with a $2.5 \mathrm{~cm}$ thick layer of expanded polystyrene fixed with silicone glue. The expanded polystyrene will serve to reduce the heat loss due to conduction.

2) Still Basin: Absorber plate: The material most have high absorbtivity or very less reflectivity and very less transmissivity. These are the criteria's for selecting the absorber plate materials ([13], [27]). For the realization of the absorber plate, we used a galvanized iron sheet measuring $1 \mathrm{~m} \times 2 \mathrm{~m} \times 1.5 \mathrm{~mm}$. For this purpose, the latter is cut into five parts and welded into a single absorber painted black to effectively absorb solar radiation and convert it to heat and transfer the heat to the water. The dimensions of which are as follows:

- Thickness: $1.5 \mathrm{~mm}$,

- Height: $0.52 \mathrm{~m}$ and $0.15 \mathrm{~m}$, 
- Base surface area: $0.4346 \mathrm{~m}^{2}$.

3) Glass cover: Ordinary glass was chosen for their good thermal conductivity, their good transmission of solar radiation and their wettability. Glass thick was used as a top cover. It is inclined at an angle of $32^{\circ}$, even an angle which is much greater than the minimum inclination $\left(15^{\circ}\right)$ from which the detachment of the drops of water condensed on the glass is avoided [28]. And other hand this angle inclination allows to increase the amount of solar radiation reaching the surface aperture more frequently during the day ([29]-[31]). The emissivity coefficient of the glass is 0.91 . The dimensions of which are as follows:

- Thickness: $6 \mathrm{~mm}$,

- Base surface area: $0.612 \mathrm{~m}^{2}$.

The distillate channel is made by polyvinyl chloride (PVC) and placed on the base of the glass cover with an inclination of $6^{\circ}$ towards the graduated cylinder to avoid of the reevaporation. To prevent vapor escape from the solar still and to ensure a good seal between the glass and the other components of the solar still, silicone glue is used. Silicone glue is flexible and easy to remove when necessary for maintenance purpose. The Fig.2 represents the prototype assembled of single slope still solar used in this work.

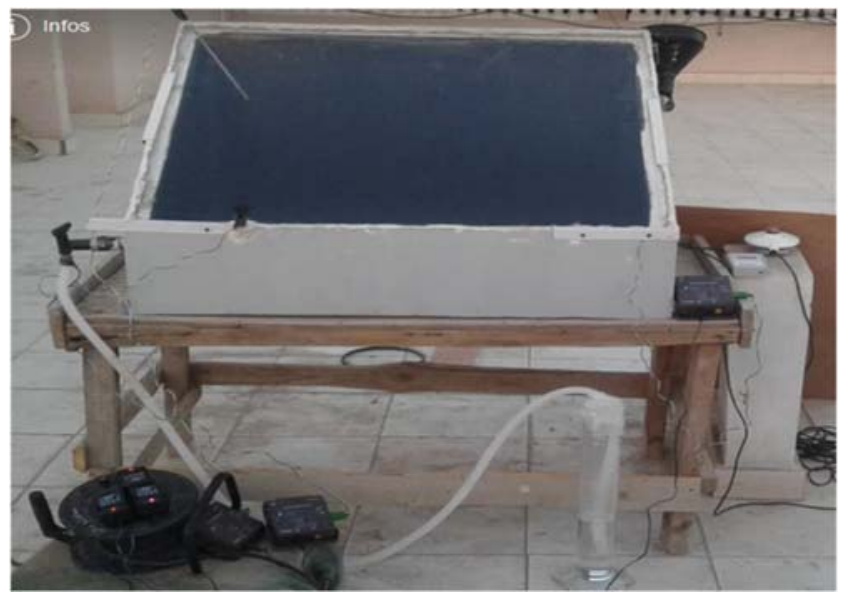

Fig. 2. Photograph view of single slope solar still.

\section{Experimental procedure}

Experiments were carried out in Djibouti city particularly in the district Balbala (GPS coordinates are of longitude E $43^{\circ} 06.681^{\prime}$ and latitude $\mathrm{N} 11^{\circ} 32.958^{\prime}$ ), Republic of Djibouti. The experiments have been conducted during the month of April-May 2019. The prototype of the solar still was placed on the terrace to get the maximum of solar radiation from 6:30 a.m. until sunset $(6: 30$ p.m). During $12 \mathrm{~h}$ of direct experiment, the measurements of the ambient temperature, glass cover temperature, vapor temperature, water temperature in basin, solar radiation, wind speed and absorber plate temperature are recorded each hour.

The single slope solar still is oriented towards East direction up 12 p.m and then orientation is changed towards West direction in order to receive most of the available solar radiation.

The temperatures at various locations in the still were measured by K-type thermocouples. The intensity of solar radiation and the glass cover temperature were measured using respectively pyranometer and pyrometer. The data of wind speed are provided by weather station, which is located Camp Lemonier of Djibouti [32] during the four days. The distillate water is measuring by graduated cylinder tube and collected in a polyethylene terephthalate (PET) bottle during each experiment.

The water used in this work is the tap water of residential district Agadalis of district Balbala. However, this tap water is drinkable but a salty flavour to some extent tolerable. Brackish water by definition has a salty taste and a higher salinity when compared with fresh water, but less saline than sea water. Brackish water refers to water with salinity of $500-17000 \mathrm{mg} / 1$ [33]. A study carried out by Abdoulkader [34] revealed that the waters supplying of Djibouti city have electrical conductivity value $4000 \mu \mathrm{S} / \mathrm{cm}$. In this case, it is thought to be this tap water to brackish water.

Chemical analyses of all samples for brackish water and distillate water which were used for the study was carried out for electrical conductivity, total dissolved solids using EC/TDS/Temperature portable meter (HANNA instruments), $\mathrm{pH}$ with $\mathrm{pH}$-meter (HANNA instruments), Chloride and hardness water using respectively method of Mohr and titration par complexometric by EDTA in the laboratory.

Fig. 3 represents the localization of various apparatus measuring used on solar still in this work. The accuracies and error limits for the various measuring apparatus are given in Table I. 
TABLE I. Accuracy and Error Limits for Various measuring Apparatus.

\begin{tabular}{|c|c|c|c|}
\hline Apparatus used & Accuracy & Range & \%Error \\
\hline Thermocouple & $0.1^{\circ} \mathrm{C}$ & $-40^{\circ} \mathrm{C} /+120^{\circ} \mathrm{C}$ & $1.5 \%$ \\
\hline Pyrometer & $2{ }^{\circ} \mathrm{C}$ & $-50^{\circ} \mathrm{C} / 600^{\circ} \mathrm{C}$ & $2 \%$ \\
\hline Pyranometer & $2 \mathrm{~W} / \mathrm{m}^{2}$ & $0-2000 \mathrm{~W} / \mathrm{m}^{2}$ & $<10 \%$ \\
\hline graduated cylinder tube & $10 \mathrm{ml}$ & $0-1000 \mathrm{~mL}$ & $10 \%$ \\
\hline
\end{tabular}

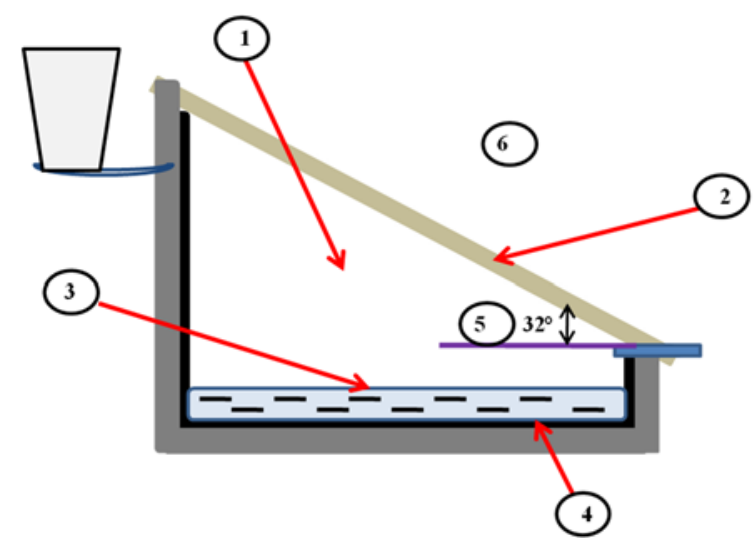

Fig. 3. Localization of various apparatus measuring used on solar still: 1) Vapor temperature, 2) Glass cover temperature, 3) Water temperature in basin, 4) Absorber plate temperature, 5) Glass cover angle, 6) Solar radiation, 7) Ambient temperature.

\section{RESULTS AND DISCUSSIONS}

In this part, the results and the discussions, during the thermal performance (manipulation without water) and the distillation phase with water, are grouped together. The experiments reported in this work have been conducted during for 4 days, 28 of April, 1, 2 and 3 of May 2019 having four different basin waters amounts of $6 \mathrm{~L}, 8 \mathrm{~L}, 10 \mathrm{~L}$ and $12 \mathrm{~L}$ of brackish water on single slope solar still under Djiboutian Climate.

\section{A. Study of thermal performance of single slope solar still without water}

Once design and construction finished, the prototype was tested without water to check the maximum temperature obtained within of single slope solar still. The Fig.4 represents the variations of temperatures of glass cover, absorber plate and ambient and solar radiation in each hour on 27 April 2019. The variation of temperatures of various components of solar still increase faster than ambient temperature and this is where the greenhouse effect begins. According in the Fig.4, it shows that absorber plate temperature reaches a value of $95.9^{\circ} \mathrm{C}$ at time 11:30 a.m which is highest for the day. This temperature obtained is close to the boiling point of water and would allow good evaporation when using the still solar with water. The variation in solar radiation during time reaches its maximum value of $1142 \mathrm{~W} / \mathrm{m}^{2}$ at 12:30 p.m and decreases from 3:30 p.m. Consequently, the performance of solar still increases when the solar radiation increases. The data obtained for the different temperatures are summarized in Table II.

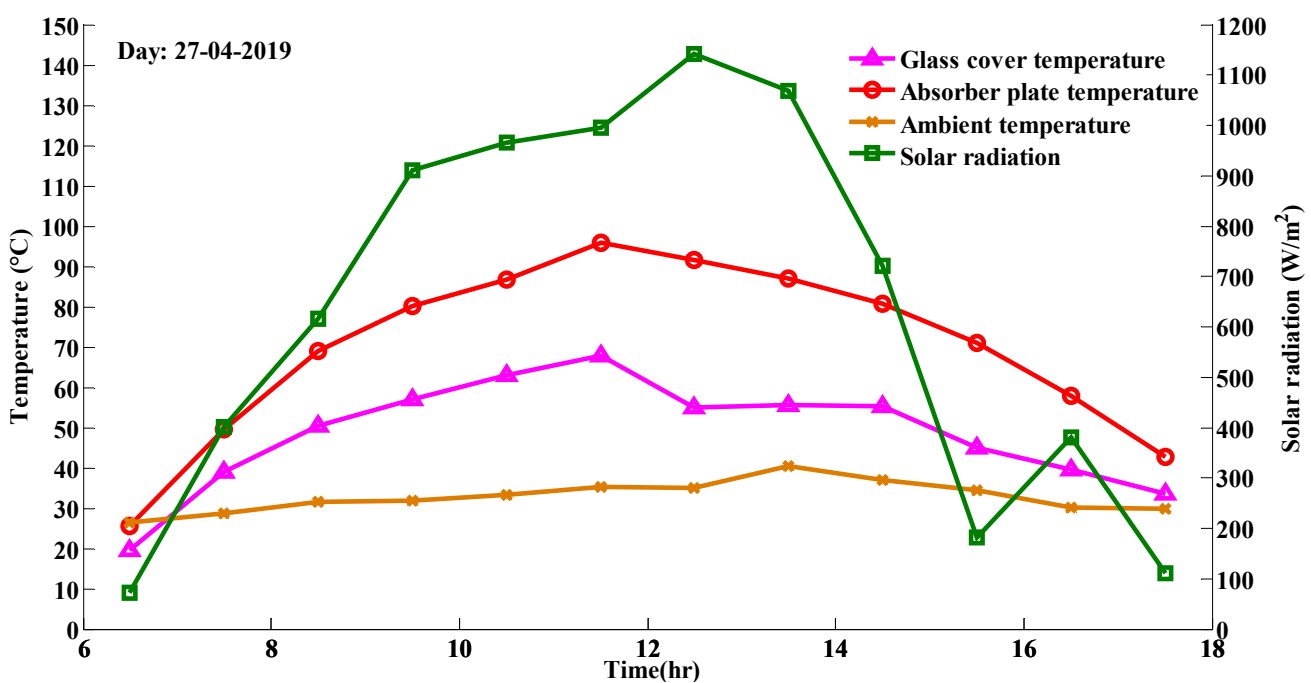

Fig. 4. Variation of various temperatures and solar radiation of solar still on 27 April 2019 without water. 
TABLE II. Ambient and Still Conditions without Water, 27 April 2019.

\begin{tabular}{|c|c|c|c|c|}
\hline Time, hr & Glass cover temp, ${ }^{\circ} \mathbf{C}$ & Absorber plate temp, ${ }^{\circ} \mathbf{C}$ & Ambient temp, ${ }^{\circ} \mathbf{C}$ & Solar radiation, $\mathbf{W} / \mathbf{m}^{2}$ \\
\hline 6.5 & 19.5 & 25.5 & 26.3 & 72 \\
\hline 7.5 & 39.1 & 49.7 & 28.8 & 402 \\
\hline 8.5 & 50.5 & 69 & 31.6 & 616 \\
\hline 9.5 & 57 & 80.2 & 31.8 & 910 \\
\hline 10.5 & 63.1 & 86.7 & 33.3 & 965 \\
\hline 11.5 & 67.8 & 95.9 & 35.3 & 995 \\
\hline 12.5 & 55.1 & 91.7 & 34.9 & 1142 \\
\hline 13.5 & 55.7 & 87.1 & 40.3 & 1069 \\
\hline 14.5 & 55.3 & 80.8 & 37 & 720 \\
\hline 15.5 & 45 & 71.1 & 34.3 & 182 \\
\hline 16.5 & 39.5 & 57.9 & 30.1 & 380 \\
\hline 17.5 & 33.5 & 42.8 & 29.8 & 110 \\
\hline
\end{tabular}

\section{B. Variations of various temperatures and solar radiation}

Fig. 5 shows the hourly variation of the received solar radiation intensity on the solar still for four different water amount in basin (i.e., $6 \mathrm{~L}, 8 \mathrm{~L}, 10 \mathrm{~L}$ and $12 \mathrm{~L}$ ) for the 4 operating days (28 April, 1, 2 and 3 May 2019) during the period from $6: 30$ a.m to $6: 30 \mathrm{p} . \mathrm{m}$. It can be observed that the solar radiation intensity received at solar still surface varies with time. It increases gradually from morning to $6: 30$ a.m to reach their maximum values at 12:30 p.m (except 1 May where the maximum value solar radiation intensity reached at 11:30 a.m) and decreases towards evening due to a low sunshine.

The maximum recorded values for solar radiation were 1048, 970, 977 and $1021 \mathrm{~W} / \mathrm{m}^{2}$ during 28 April, 1, 2 and 3 May 2019, respectively. On the 1 May, it can be noticed that, there is one point which show a decreasing trend of solar radiation intensity at mid-noon. This is due to a very few clouds that cover the sky.

As shown in the Fig. 5, the trend solar radiation intensity is almost similar to all four days, but there is a small difference in the values of solar radiation. This difference in these values of solar radiation intensity is due to the change climatic conditions during these 4 days.

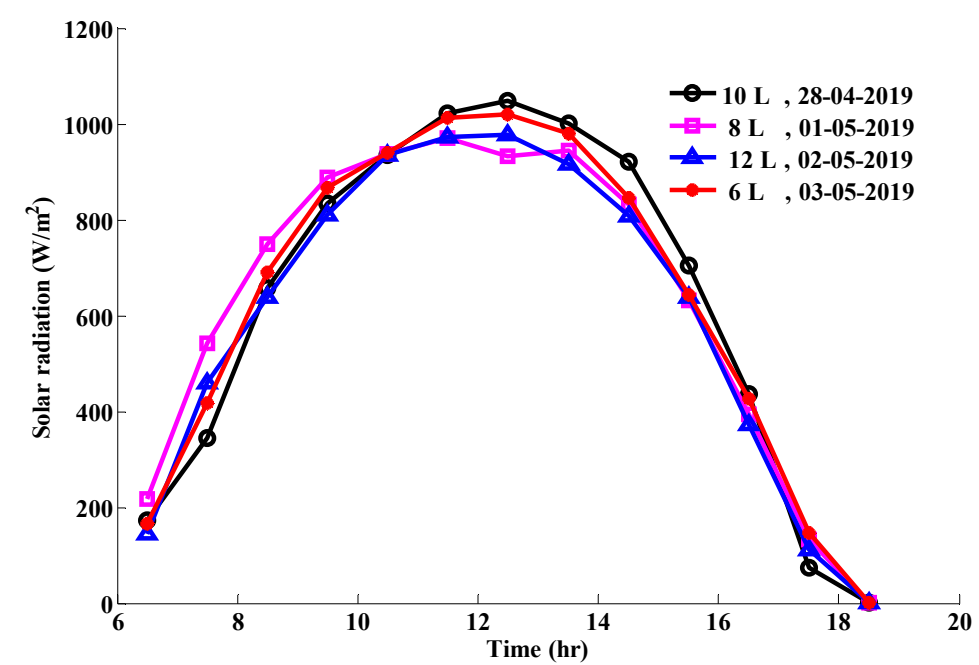

Fig. 5. Trend of solar radiation during the operating days with different water amount in basin.

Fig. 6, 7, 8 et 9 show the hourly variation ambient temperature, water temperature in basin, absorber plate temperature, glass cover temperature and vapor temperature with the time for the 4 operating days 28 th of April, 1 st, 2 th and 3 th of May 2019 having four different water amount in the basin. The results show that variations of the all temperatures increased gradually on solar radiation intensity and obtained high values temperatures during period 12:30 p.m - 3:30 p.m.

It can be seen in these figures that the vapor temperature is the maximum for all the four days of experiments followed by water temperature in basin, absorber plate temperature, glass cover temperature and ambient temperature. The variation in the vapor temperature can be attributed to the variation in basin temperature which affects the natural air circulation currents inside the solar still [35]. These results are in agreement with these 
reported by Badran [19] and Orisaleye et al. [36]. The vapor temperature ranges between $40.8-82.2^{\circ} \mathrm{C}, 39$ $93.7^{\circ} \mathrm{C}, 25.1-67.5^{\circ} \mathrm{C}$ and $31.4-76.4^{\circ} \mathrm{C}$ during the operating days of 28 April, 1,2 and 3 May respectively.

It was also observed that the absorber plate temperature and water temperature in the basin are almost similar for all the test days, of course with slight differences. The maximum absorber plate temperature reached $72.2^{\circ} \mathrm{C}$, $79.9^{\circ} \mathrm{C}, 78.7^{\circ} \mathrm{C}$ and $81.7^{\circ} \mathrm{C}$, where as the maximum water temperature in basin recorded is found to be $77.3^{\circ} \mathrm{C}$, $78.7^{\circ} \mathrm{C}, 79^{\circ} \mathrm{C}$ and $83.7^{\circ} \mathrm{C}$ with a maximum solar intensity of $1048,970,977$ and $1021 \mathrm{~W} / \mathrm{m}^{2}$, respectively, during the operating days of 28 April, 1, 2 and 3 May, respectively. This is due to of the continuous contact between them which lead to heat equilibrium ([20], [37]). The variation absorber plate temperature is mainly due to the high ability of basin material to absorb heat. These observations are consistent the results of ([38][39]).

As can be seen in these figures, the ambient air temperature is lower when compared to all surface temperature. The ranges of the ambient temperature within $12 \mathrm{~h}$ are $27.4-34.1{ }^{\circ} \mathrm{C}, 27.7-36.3^{\circ} \mathrm{C}, 29.9-37.1{ }^{\circ} \mathrm{C}$ and $28-37.2^{\circ} \mathrm{C}$ during the operating days of 28 April, 1, 2 and 3 May respectively, with high temperatures always observed at 12:30 p.m - 3:30 p.m.

The water temperature in at basin solar still is higher than that at of the glass cover temperature as shown in these figures during of 4 days of experiments. This is due to the fact that the water in the basin is being heated by the absorber plate and by a fraction of solar radiation passing through the glass cover [40].

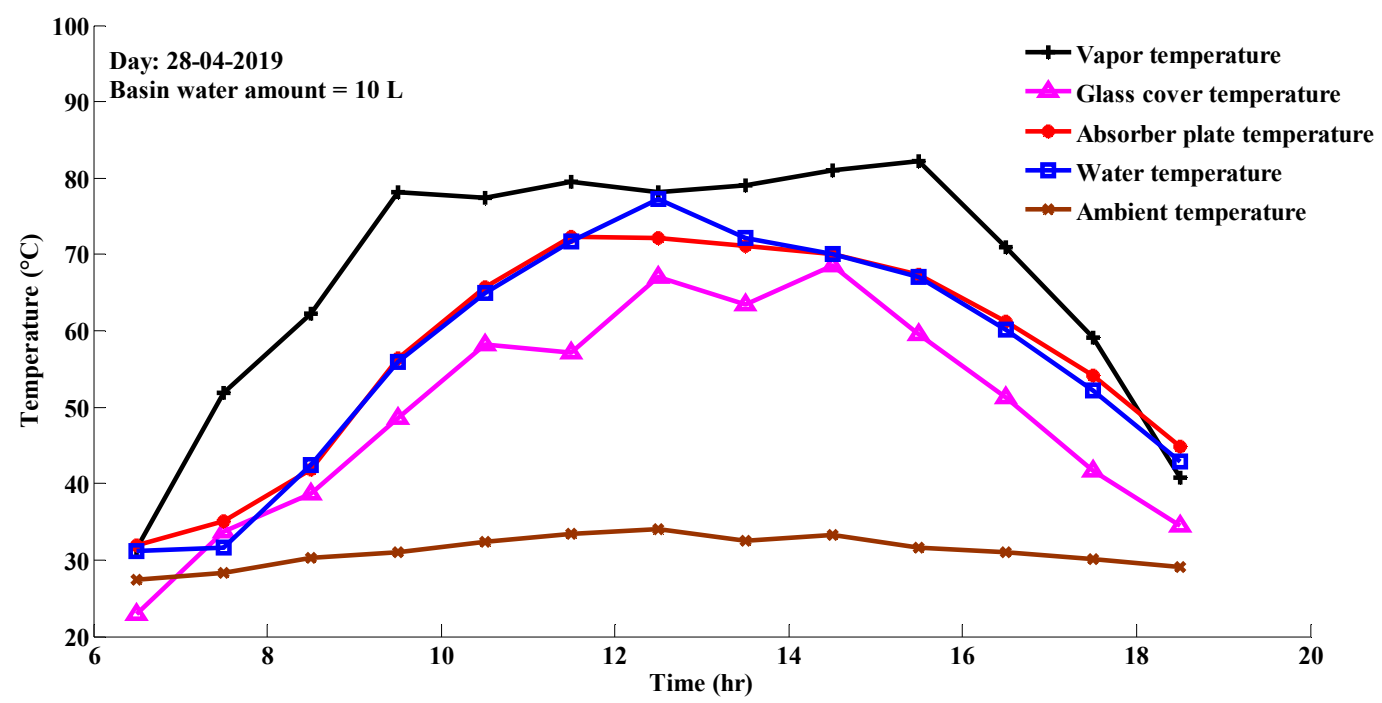

Fig. 6. Diurnal variations in temperatures of water, glass cover, absorber plate, vapor and ambient on 28 April 2019.

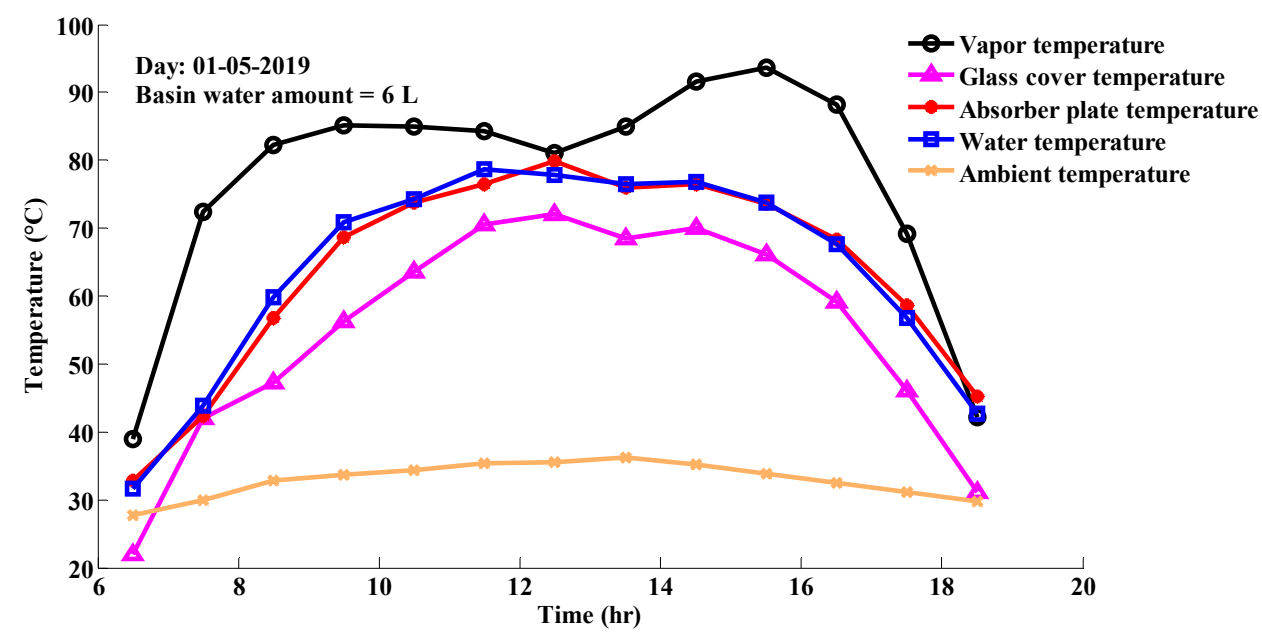

Fig. 7. Diurnal variations in temperatures of water, glass cover, absorber plate, vapor and ambient on 01 May 2019. 


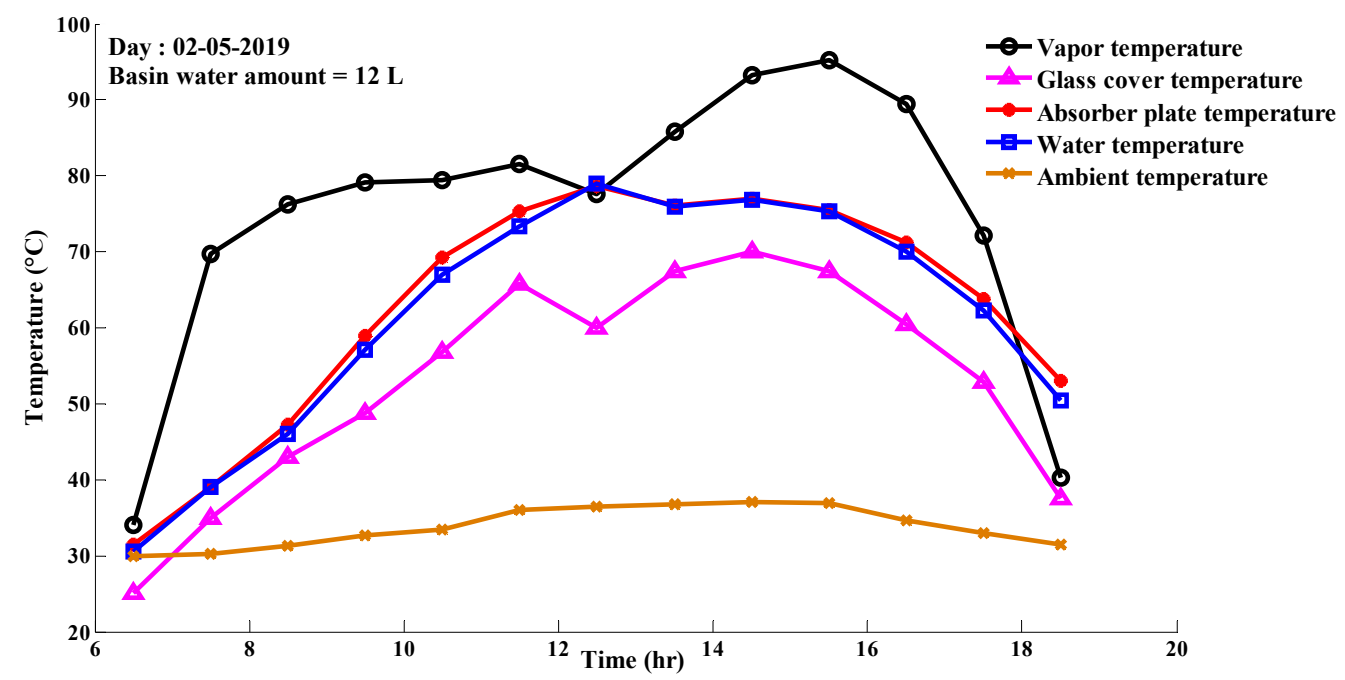

Fig. 8. Diurnal variations in temperatures of water, glass cover, absorber plate, vapor and ambient on 02 May 2019.

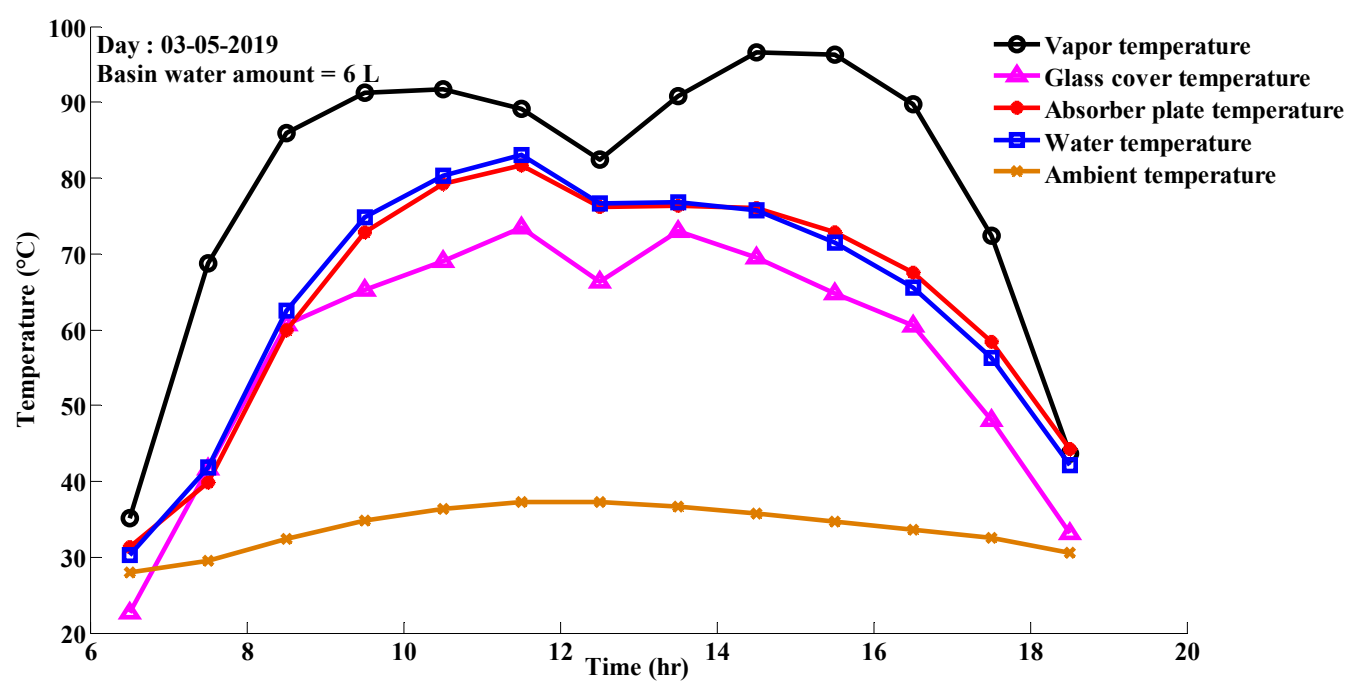

Fig. 9. Diurnal variations in temperatures of water, glass cover, absorber plate, vapor and ambient on 03 May 2019.

\section{Effect of basin water amount on water production}

Fig. 10 represents hourly cumulative productivity obtained for different water amount in the solar still basin (i.e., $6 \mathrm{~L}, 8 \mathrm{~L}, 10 \mathrm{~L}$ and $12 \mathrm{~L}$ ). From the experimental results, it is found that the total accumulated distillate output for the solar still is $2490 \mathrm{~mL}, 2390 \mathrm{~mL}, 2240 \mathrm{~mL}$ and $2015 \mathrm{~mL}$ during the operating days of 28 April, 1 , 2 and 3 May respectively. However, it was observed that the volume of distilled water output varied inversely with the amount of water in the basin. It is clearly observed that the maximum cumulative productivity is obtained from a low water amount $(6 \mathrm{~L})$ in the basin of solar still and minimum for a high water amount $(12 \mathrm{~L})$. It can be concluded that the increase in productivity is due to the high evaporation rate obtained at lower water amount $(6 \mathrm{~L})$ compared with the other three water amount $(8 \mathrm{~L}, 10 \mathrm{~L}$ and $12 \mathrm{~L})$, because the temperature of the water in basin growing rapidly for a lower basin water amount.

With the increase in basin water amount from $6 \mathrm{~L}$ to $8 \mathrm{~L}, 6 \mathrm{~L}$ to $10 \mathrm{~L}$ and $6 \mathrm{~L}$ to $12 \mathrm{~L}$, water cumulative production from solar still reduces by $4.01 \%, 10.04 \%$ and $19.07 \%$, respectively.

The results obtained are a good agreement with the experimental studies carried out by other researchers ([41]-[42]). They showed that the water depth has a significant effect on the water productivity. 


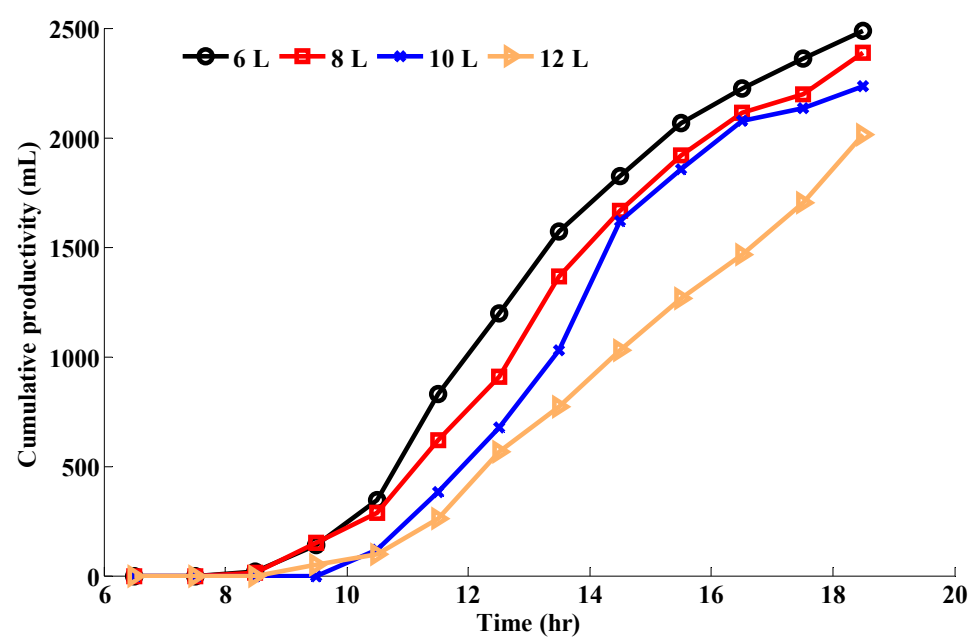

Fig. 10. Variations of cumulative water productivity with different basin water amount during the operating days.

\section{Relationship between wind speed and water production}

The wind speed was observed to have a significant effect on solar still water production ([10], [12], [43] [45]). Fig. 11 represents the variation of cumulative water productivity with average daily wind speed. At the minimum cumulative water productivity of $2015 \mathrm{~mL} /$ day, average wind speed was obtained as $11.09 \mathrm{~km} / \mathrm{h}$. The average wind speed of $13.44 \mathrm{~km} / \mathrm{h}$ was occurred at the maximum cumulative water productivity of $2490 \mathrm{~mL} /$ day. The maximum average daily wind speed of $14.36 \mathrm{~km} / \mathrm{h}$ gives as cumulative productivity as $2240 \mathrm{~mL} /$ day. Therefore, it is revealed the cumulative productivity increases when the wind speed average increase and high wind speed give less development in yield than reasonable wind speed [17]. However, increasing velocity of wind cooling down the temperature of the glass cover and consequently increases the condensation rate as well as increasing solar still productivity ([46]-[47]). As the glass cover temperature decreases, the productivity increases [11].

Many authors have studied the effect of wind speed with different designs solar still on the productivity of solar still. It has been demonstrated that the increase in wind speed causes an increase in productivity ([45], [48]-[56]). According to the literature, the effect of wind speed on the productivity can be explained by the convective heat transfer coefficient from glass cover which increases and temperature difference between water and inner side glass cover increase as well. As a result the performance of solar still is enhanced ([45], [55], [57]-[58]).

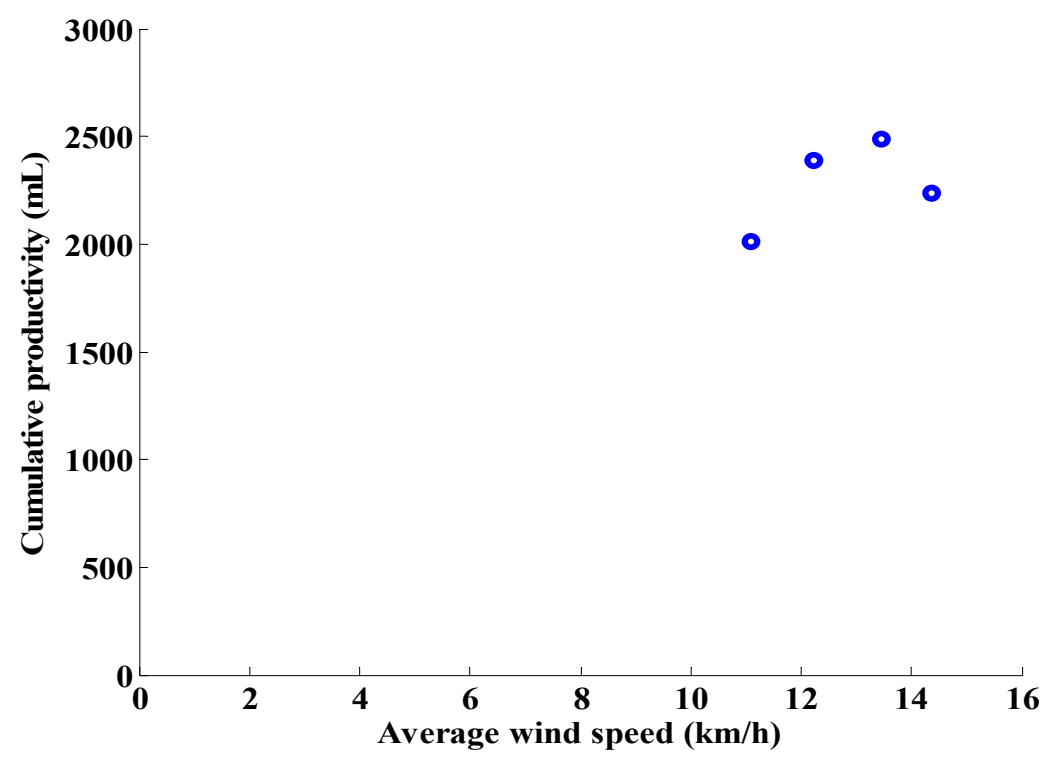

Fig. 11. Variation of cumulative water productivity with average daily wind speed. 


\section{E. Analysis of water quality before and after purification with solar still}

Table III shows the different water quality parameters, namely $\mathrm{pH}$, total dissolved solids (TDS), electrical conductivity (EC), hardness water and chloride, of the distilled water produced from brackish water and to compare the World Health Organization (WHO) standards for drinking water. The values of total dissolved solids (TDS), hardness water, chloride and electrical conductivity (EC) reduced from 2340, 632, $2023.5 \mathrm{mg} / \mathrm{l}$, $4700 \mu \mathrm{S} / \mathrm{cm}$ before experiment to $43,16.2,93.2 \mathrm{mg} / \mathrm{l}$ and $74 \mu \mathrm{S} / \mathrm{cm}$ after experiment, respectively. Four values obtained after distillation were within the accepted range of WHO standards drinking water. Furthermore, a good percentage (>95\%) of removal was noticed for four parameters TDS, EC, hardness water and chloride [26]. In the literature several studies, relating to different types of water (namely lake water, sea water, groundwater, brackish water, river water and domestic water) with different design of solar still, have reported that the water produced is in fair agreement and conforming WHO guidelines ([25], [27], [59]-[62]).

The $\mathrm{pH}$ values were reduced to 4.32 (distilled water) from 7.75 (Brackish water) and are not within the WHO limits of drinking water (Table III). According to the literature, this acidity of the distillate can be explained by the dissolution of carbon dioxide and turns into carbonic acid [63]. Deliou et al. [28] can be found the same results in her experimentation of double slope still solar.

TABLE III. Water Quality Parameters of Product Water from Brackish water
\begin{tabular}{|l|c|c|c|c|}
\hline \multicolumn{1}{|c|}{ Water quality parameters } & $\begin{array}{c}\text { Brackish water } \\
\text { (before) }\end{array}$ & Distilled water (after) & Removal \% & $\begin{array}{c}\text { WHO standards } \\
{[64]}\end{array}$ \\
\hline $\mathrm{pH}$ & 7.75 & 4.32 & - & $6.5-8.5$ \\
\hline Total dissolved solids $(\mathrm{TDS}, \mathrm{mg} / \mathrm{l})$ & 2340 & 43 & 98.16 & $<600$ \\
\hline Electrical conductivity $(\mathrm{EC}, \mu \mathrm{S} / \mathrm{cm})$ & 4700 & 74 & 98.42 & $<250$ \\
\hline Hardness water $\left(\mathrm{mg} / \mathrm{l} \mathrm{CaCO}_{3}\right)$ & 632 & 16.2 & 97.43 & 200 \\
\hline Chloride $(\mathrm{mg} / \mathrm{l})$ & 2023.5 & 93.2 & 95.39 & 250 \\
\hline
\end{tabular}

\section{IV.CONCLUSION}

The paper aims at developing a device allowing converting saline or brackish water into fresh water and has the advantage of being easy to construct and requires less maintenance. Therefore, a low cost single slope solar still (SSSS) was fabricated with simple, cheap and available materials. Different parameters affecting solar still productivity, such as effect different amount water in the solar still basin and effect wind speed, were evaluated under climatic condition of Republic of Djibouti. It was found that a low water amount $6 \mathrm{~L}$ gives the maximum cumulative productivity $2490 \mathrm{~mL} / \mathrm{day}$. In addition, the wind speed has been found to have a significant effect on water production of the solar still. Analyses of water quality after purification with solar still for four parameters TDS, EC, hardness water and chloride respected ranges of drinking water guidelines of the World Health Organization.

The use of the solar still, especially for rural and coastal populations, offers an economically advantageous alternative while purifying groundwater, all types of surface water, brackish water and seawater in fresh water to produce good quality water while preserving their health.

\section{ACKNOWLEDGMENT}

The author wishes to thank students Bachelors degree in Environmental Chemistry of Faculty of Sciences for their assistance during experimental measurements with the solar still for the present paper. We express gratitude to University of Djibouti for financially support from this research work.

\section{REFERENCES}

[1] A. Bhattacharyya, "Solar Stills for Desalination of Water in Rural Households," International Journal of Environment and Sustainability, 2, 21-30, 2013.

[2] M.W. Akram, S.M. Abdul Motin, M.A. Hoque, N.N. Mustafi, "Design, Construction and Performance Test of a Solar Still for Water Desalination in Bangladesh Perspective," AIP Conference Proceedings 2121, 130001-1 - 130001-7, 2019.

[3] DISED. (2021) presidence [Online]. Available [https://www.presidence.dj/sousmenu.php?ID=18].(access date 8 February 2021)

[4] International Monetary Fund, Djibouti: Poverty Reduction Strategy, Paper.22, 2004.

[5] E. Idil Mouhoumed, M. Mohamed-awal Abdillahi, Y. Mouhoumed Elmi, C. Osman Doubad and E. Abdoulnasser Dirieh, "Classification of Various Bottled Mineral Waters Marketed in Djibouti," World Journal of Engineering and Technology, 8, 720-738, 2020.

[6] A. I. Idriss, A. I. Omar, M-A. A. Mohamed, O. A. Mohamed and O. A. Dabar, "Thermal Performance Testing and Promotion of Solar Cooker under Djiboutian Climate", International Journal of Engineering and Technology, 9, 2552-2558, 2017.

[7] B. Bouchekima, B. Gros, R. Oahes, M. Diboun, "Performance study of the capillary film solar distiller," Desalination, 116, 185-192, 1998. 
[8] V. Velmurugan and K. Srithar, "Performance analysis of solar stills based on various factors affecting the productivity-a review," Renewable and Sustainable Energy Reviews, 15(2), 1294-1304, 2011.

[9] B. Bouchekima, "A solar desalination plant for domestic water needs in arid areas of South Algeria," Desalination, 153, 65-69, 2002

[10] M. Husham Ahmed, S. Faisal Alshutal, and I. Ghaleb, "Impact of Different Configurations on Solar Still Productivity," Journal of Advanced Science and Engineering Research, 4, 118-126, 2014.

[11] S. Mohammed Shadi Abujazar, S. Fatihah, A.R. Rakmi, M.Z. Shahrom, "The effects of design parameters on productivity performance of a solar still for seawater desalination: A review," Desalination, 385, 178-193, 2016.

[12] S. Nafey, M. Abdelkader, A. Abdelmotalip, A.A. Mabrouk, "Parameters affecting solar still productivity," Energy Conversion and Management, 41, 1797-1809, 2000.

[13] S. Kandasamy, M. Vellingiri, S. Sengottain, J. Balasundaram, "Performance correlation for single-basin double-slope solar still," International Journal of Energy and Environmental Engineering, 4, 1-6, 2013.

[14] AW. Marwah Ali and N. Abdul Jabbar Khalifa, "Indoor tests to investigate the effect of brine depth on the performance of solar still," 4, 211-218, 2013

[15] T. Elango and K. Kalidasa murugavel, "The effect of the water depth on the productivity for single and double basin double slope glass solar stills," Desalination, 359, 82-91, 2015.

[16] N. Hitesh Panchal and S. Patel, "Effect of Various Parameters on Augmentation of Distillate Output of Solar Still: A Review," Technol Econ Smart Grids Sustain Energy, 1-4, 2016.

[17] A. Agrawal, R.S. Rana, P.K. Srivastava, "Heat transfer coefficients and productivity of a single slope single basin solar still in Indian climatic condition: Experimental and theoretical comparison," Resource-Efficient Technologies, 1-17, 2017.

[18] J.I. Orisaleye, S.O. Ismail, M. Ogbonnaya, A.A. Ogundare, "Development and performance evaluation of a solar water still," Acta Technica Corviniensis- Bulletin of Engineering, Tome XI, 91-96, Fascicule 1 [January - March] 2018.

[19] M. S. K. Tarawneh, "Effect of Water Depth on the Performance Evaluation of Solar Still," Jordan Journal of Mechanical and Industrial Engineering, 1, 23-29, Sep. 2007.

[20] O.O. Badran, M.M. Abu-Khader, "Evaluating thermal performance of a single slope solar still," Heat Mass Transf, 43, 985-995, 2007.

[21] A. Khalid Alfaylakawi and M.Husham Ahmed, "An experimental study on the effect of wind speed and water sprinklers on simple solar still productivity”, III. International Conference on Nuclear \& Renewable Energy Resources İstanbul, TURKEY, May 2012.

[22] M. Edwin and S.J. Sekhar," Performance and Chemical Analysis of Distilled Saline Water Production Using Solar Distillation System," International Journal of ChemTech Research, 8(4), 1632-1637, 2015.

[23] R.S. Hansen and K. Kalidasa Murugavel, "Enchancement of Integrated Solar Still Using Different New Absorber Configurations: An Experimental Approach,” Desalination, 422, 59-67, 2017.

[24] A. Ahsan, M. Imteaz, U.A. Thomas , M. Azmi, A. Rahman, N.N. Nik Daud, "Parameters affecting the performance of a low cost solar still," Applied Energy, 114, 924-930, 2014b.

[25] A. Ahsan, N. Syuhada, E. Jolhi, Kh.M. Darain, Md.K. Rowshon, Md. Jakariya, Suhaidi Shafie and Abdul H. Ghazali, "Assessment of distillate water quality parameters produced by solar still for potable usage," Fresenius Environmental Bulletin, 23, 859-866, 2014a.

[26] A. Hoque, A. H. Abir, K. P. Shourov, "Solar still for saline water desalination for low-income coastal areas," Applied Water Science, 9:104, 1-8, 2019.

[27] S. B. Danjuma, A. M. Lawal, I. S. Muhammad and O. Y. Usman, "Design Construction and Performance Evaluation of Solar Still for Rural Dwellers," Vol 4, 1001-1008, 2018.

[28] A. Deliou, N. Bessas, Z. Belgroun, H. Aburideh, A. Lounis and A. Chikouche, "Etude expérimentale des caractéristiques d'un distillateur solaire à effet de serre," Revue des Energies Renouvelables CICME'08 Sousse, 109-118, 2008.

[29] H.Ş. Aybar, Fuat Egelioğlu and U. Atikol, "An experimental study on an inclined solar water distillation system," Desalination, 180, 285$289,2005$.

[30] A. kabi and O. Halloufi," Performance Study of a Solar Still a Solar Preheating of Brackish Water," International Journal of Advances in Agricultural \& Environmental Engineering, 2(2), 94-97, 2015.

[31] T. Elango, A. Kannan and K. Kalidasa Murugavel, "Performance study on single basin single slope solar still with different water nanofluids," Desalination, 360, 45-51, 2015.

[32] Camp Lemonier, "Utilization of meteosat satellite radiation data for Republic of Djibouti," 2019, https://www.infoclimat.fr/observationsmeteo/temps-reel/camp-lemonier/69675.html (access date 28 April - 3 May 2019)

[33] L.N. Nthunya, S. Maifadi, B.B. Mamba, A.R. Verliefde, S.D. Mhlanga, "Spectroscopic Determination of Water Salinity in Brackish Surface Water in Nandoni Dam, at Vhembe District, Limpopo Province, South Africa," Water, 10, 1-13, 2018.

[34] A. Houssein Ahmed,"Caracterisation hydrogeochimique et qualité des eaux souterraines du système aqifère volcano-sédimentaire cotier sous climate ride de Djibouti (Afrique de l'Est)" Thèse, École Doctorale Sciences de la Matière, du Rayonnement et de 1‘Environnement, Université de Lille 1, France, Décembre 2014.

[35] T. Alheefi, "Experimental and analytical study of water production of solar still," Thesis, College of Engineering, Design and Physical Sciences, Brunel University London, United of Kingdom, May 2019.

[36] O.O. Badran, "Experimental study of the enhancement parameters on a single slope solar still productivity, "Desalination, 209, 136-143, 2007.

[37] S.Varun raja, A.Muthu Manokarb, "Design and Analysis of Solar Still”, Materials Today: Proceedings, 4, 9179-9186, 2017.

[38] Ye. Shakir, M. Mohanraj, Ye. Belyayev, S. Jayraj, A. Kaltayev, "Numerical simulation of a heat pump assisted regenerative solar still for cold climates of Kazakhstan," Bulgarian Chemical Communication, 48, 126-132, 2016.

[39] A. Kabeel, Y. Taamneh, R. Sathyamurthy, P.N. Kumar, A.M, Manokar and T. Arunkumar, "Experimental studyon conventional solar still integrated with inclined solar still under different water depth," Heat Transfer-Asian Res, 1-15, 2018.

[40] M. Al-harahsheh, M. Abu-Arabi, H. Mousa and Z. Alzghoul, "Solar desalination using solar still enhanced by external solar collector," Applied Thermal Engineering, 128, 1030-1040, 2018.

[41] A.A. Ghassan and A.A. Salem, "Exploring of Water Distillation by Single Solar Still Basins," American Journal of Climate Change, 2, $57-61,2013$

[42] A.M. Al Shabibi and M. Tahat; "Thermal Performance of a Single Slope Solar Still with Enchanced Solar Heating System," Renewable Energy and Power Quality Journal, 1 (13), April 2015.

[43] V. Dimri, B. Sarkar, U. Singh and G.N. Tiwari, "Effect of condensing cover material on yield of an active solar still:an experimental validation," Desalination, 227, 178-189, 2008

[44] G.N Tiwari, V. Dimri, Chel Arvind, "Parametric study of an active and passive solar distillation system: energy and Exergy analysis," Desalination, 242, 1-18, 2009.

[45] A.A. El-Sebaii, "On effect of wind on passive solar still performance based on inner/outer surface temperatures of glass cover," Energy, 36, 4943-4949, 2011. 
[46] V. Velmurugan, C.K. Deenadayalan, H. Vinod, K. Srithar, "Desalination of effluent using fin type solar still," Energy, 33, 1719-1727, 2008.

[47] V. Velmurugan, K.J. Naveen Kumar, T. Noorul Haq, K. Srithar, "Performance analysis in stepped solar still for effluent desalination," Energy, 34, 1179-1186, 2009.

[48] S.H. Soliman, "Effect of wind on solar distillation," Solar Energy, 13, 403-415, 1972.

[49] M.A.S. Malik and V. Tran,"A simple mathematical model for predicting the nocturnal output of a solar still, " Solar Energy, 14, 371-385, 1973.

[50] H. P. Garg and H. S. Mann, "Effect of climatic, operational and design parameters on the year-round performance of single-sloped and double-sloped solar stills under Indian arid zone conditions, " Solar Energy, 18, 159-164, 1976.

[51] P. I. Cooper, "Digital simulation of transient solar still performance," Solar Energy, 12, 159-164, 1976.

[52] A. K. Rajvanshi, "Effect of various dyes on solar distillation," Solar Energy, 27, 51-65, 1981.

[53] A.A. El-Sebaii, "Effect of wind speed on some designs of solar still," Energy Conversion \& Management, 41, 523-538, 2000.

[54] V. Dimri, B. Sarkar, U. Singh and G.N. Tiwari, "Effect of condensing cover material on yield of an active solar: an experimental validation," Desalination, 227, 178-189, 2008.

[55] A.A. El-Sebaii, S.J. Yaghmour, F.S. AL-Hazmi A.S. Faidah, F.M. Al-Marzouki and A.A. Al-Ghamdi, "Active single basin solar still with a sensible storage medium," Desalination, 249, 699-706, 2009.

[56] G.N. Tiwari V. Dimri and Chel Arvind, "Parametric study of an active and passive solar distillation system: energy and Exergy analysis," Desalination, 242, 1-18, 2009.

[57] R.M. Reddy and K.H. Reddy,"Upward heat flow analysis in basin type solar still," J.Min.Metall, 45, 121-126, 2009.

[58] A. F. Muftah, M. A. Alghoul, A. Fudholi, M.M. Abdul-Majeed and K. Sopian, "Factors affecting basin type solar still productivity: a detailed review," Renew. Sust. Energ. Rev, 32, 430-447, 2014.

[59] S. Kumar and G. N. Tiwari, 2009, "Life Cycle Cost Analysis of Single Slope Hybrid (PV/T) Active Solar Still," Applied Energy, 86 (10), 1995-2004, 2009.

[60] Raza, Saleem, K.C. Mukwana and M.M. Tunio, “ Experimental Study of Desalination Technologies and Timer-Based Solar PV Tracking System, " Quaid-e-Awam University Research Journal of Engineering, Science \& Technology, 13(1), 1-6, 2014.

[61] T. Arunkumar, R. David Denkenberger, R. Velraj, R. Sathyamurthy, H. Tanaka and K. Vinothkumar, “ Experimental study on a Parabolic Concentrator Assisted Solar Desalting System, "Energy Conversion and Management, 105, 665-674, 2015,

[62] Saha, Sharvil, N. Mistry, I. Husein and J. Nilesh, "Design and Construction of Solar Water Distillation System," International Journal of Scientific Research in Science Engineering and Technology, 3, 606-610, 2017.

[63] S. Gorjian, B. Ghobadian, T.T. Hashjin and A. Banakar, "Experimental performance evaluation of a stand-alone point-focus parabolic solar still,” Desalination, 352, 1-17, 2014.

[64] World Health Organization (WHO), Guidelines for drinking-water quality: 4th ed. incorporating first addendum. Geneva, Switzerland, 2017.

\section{AUTHOR PROFILE}

Mohamed-awal Abdillahi Mohamed is senior lecturer in chemistry at the University of Djibouti. Since 2009 at 2014, he is working as an Assistant Professor in Chemistry at the Faculty of Sciences. During 2014, he received his Ph.D degree from the institute UTINAM (Universe, Time-Frequency, Interfaces, Nanostructures, Atmosphere and Environment, Molecules) which is a multidisciplinary research laboratory under the joint supervision of the CNRS and the University of Franche-Comté (France). His main areas of research interest are the treatment of water contaminated by Heavy metal.

Idil Mouhoumed Elmi is senior lecturer in chemistry at the University of Djibouti. Since 2011 at 2016, she was working as an Assistant Professor in Chemistry at the Faculty of Sciences. Early 2016, she received her $\mathrm{Ph} . \mathrm{D}$ degree in Process Engineering from Institut de Sciences Chimiques de Rennes of the University of Rennes 1 (France). Her research interests in the surface characterization, transport modeling, water treatment using membrane process and water desalination using renewable energy sources (such as solar energy) as well as the water quality. 